\title{
Pengalaman Penderita DM Tipe 2 dalam Pengendalian Kadar Gula Darah
}

\author{
Rusdianingseh, Difran Nobel Bistara \\ Universitas Nahdlatul Ulama Surabaya, Fakultas Keperawatan dan Kebidanan, \\ Profesi Ners, Jl. Smea No.57, Wonokromo, Kecamatan Wonokromo, Kota \\ Surabaya, Jawa Timur \\ Email: rusdia@unusa.ac.id
}

$\begin{array}{ll}\text { Diterima tanggal } & : \text { 13 September } 2020 \\ \text { Direvisi tanggal } & : \text { 19 November } 2020 \\ \text { Dipublikasikan tanggal } & : \text { 10 Desember } 2020\end{array}$

\begin{abstract}
Abstrak
Latar Belakang dan Tujuan: Hiperglikemi pada pasien DM disebabkan oleh gangguan sekresi insulin atau kerja insulin yang tidak adekuat. Sel tubuh yang tidak memberikan respon terhadap gangguan sekresi insulin, atau tidak bisa memanfaatkan secara optimal, maka akan mengalami penumpukan gula darah dalam tubuh. Penelitian ini bertujuan untuk mengetahui arti dan makna pengalaman penderita DM tipe 2 dalam pengendalian kadar gula darah di wilayah Kebonsari Surabaya.

Metode: Penelitian ini menggunakan desain fenomenologi deskriptif. Pengumpulan data dilakukan dengan indept interview. Partisipan dalam penelitian ini adalah penderita DM tipe 2 yang tinggal dengan keluarganya di wilayah Kebonsari Surabaya. Data yang dikumpulkan berupa rekaman wawancara dan catatan lapangan. Hasil transkrip verbatim dianalisis menggunakan metode Open Code4.02.

Hasil: Penelitian mengidentifikasi 4 tema yaitu pemahaman tentang DM, penyesuaian pola hidup, terapi DM dan kesulitan dalam pengendalian DM.

Simpulan dan Implikasi: Pentingnya pemahaman tentang DM, penyesuaian pola hidup, terapi dan pengendalian DM menjadi dasar perlunya program dan panduan peningkatan pengetahuan serta ketrampilan pengendalian DM tipe 2 di rumah.
\end{abstract}

Kata Kunci: DM tipe 2; Pengalaman; Pengendalian

Sitasi: Rusdianingseh \& Bistara D N. (2020). Pengalaman penderita DM tipe 2 dalam pengendalian kadar gula darah. The Indonesian Journal of Health Science. 12(2), 121-129

Copyright: () 2020 Rusdianingseh et al. This is an open-access article distributed under the terms of the Creative Commons Attribution-NonCommercial 4.0 International License, which permits unrestricted use, distribution, and reproduction in any medium, provided the original author and source are credited.

Diterbitkan Oleh: Universitas Muhammadiyah Jember

ISSN (Print): 2087-5053

ISSN (Online): 2476-9614 


\begin{abstract}
Introduction and Aim: hyperglycemia caused impaired insulin secretion or inadequate insulin action. The Body cells that do not respond to insulin secretion disorders, or cannot utilize it optimally, will experience a buildup of blood sugar in the body. This study aims to determine the meaning of the experience of type 2 DM sufferers in controlling blood sugar levels in Kebonsari Surabaya.

Methods: This study used a descriptive phenomenology design. Data collection was done by indept interview. Participants in this study were people with type 2 diabetes who lived with their families in Kebonsari Surabaya. The data collected in the form of interview records and field notes. The results of the verbatim transcripts were analyzed using the Open Code4.02 method.

Results: The study identified the theme of understanding DM, adjustment of lifestyle, DM therapy and difficulties in controlling DM.

Conclusion: The importance of understanding DM, adjustment of lifestyle, DM therapy and control is the basis for the need for programs and guidelines to increase knowledge and skills of controlling type 2 DM at home.
\end{abstract}

Keywords: Controlling; Experience; Type 2 DM,

\section{PENDAHULUAN}

Diabetes mellitus merupakan suatu kondisi tingginya kadar gula darah dalam tubuh yang diakibatkan oleh berkurangnya hormon insulin yang membutuhkan pengobatan antidiabetes (Soegondo, Soewondo \& Subekti, 2011; Miller, 2012). Diabetes adalah penyakit kronis serius yang terjadi karena pankreas tidak menghasilkan cukup insulin (hormon yang mengatur gula darah atau glukosa), atau ketika tubuh tidak dapat secara efektif menggunakan insulin yang dihasilkannya.

Penderita Dibates mellitus semakin meningkat setiap tahunnya. Berdasarkan data WHO bahwa di dunia terdapat 422 juta penderita diabetes mellitus yang berusia di atas 18 tahun (WHO, 2016). Penderita diabetes mellitus di Indonesia menduduki peringkat ke-enam setelah Cina, India, US. Brazil dan Meksiko dengan jumlah di Indonesia mencapai 10.3 juta penderita dan akan meningkat sekitar $11.1 \%$ pada tahun 2045 (IDF, 2017).
Berdasarkan data dari Pusat data dan Informasi kementrian Kesehatan Indonesia tahun 2018, penderita diabetes mellitus di Indonesia meningkat dari 8.4 juta pada tahun 2013 menjadi 21.3 juta penderita pada tahun 2030. Data tersebut juga tidak jauh berbeda dengan data di Riset kesehatan Dasar bahwa prevalensi penderita diabetes mellitus di tingkat nasional meningkat dari $6.9 \%$ pada tahun 2013 menjdai $8.5 \%$ pada tahun 2018 . Angka kejadian juga meningkat di Jawa Timur dari $2.1 \%$ pada tahun 2013 menjadi $2.6 \%$ pada tahun 2018 (Riskesdas, 2018).

Tingginya jumlah penderita diabetes mellitus tipe 2 dipengaruhi oleh beberapa faktor risiko, antara lain faktor genetik, faktor demografi dan faktor perilaku (gaya hidup) (Suyono, 2011). Gaya hidup yang dimaksud adalah meliputi penaturan nutrisi (diet), latihan fisik dan manajemen stres yang tidak tepat memegang peranan penting. Leake dan Reynolds (2004), dalam 
penelitiannya terhadap penderita diabetes mellitus di Philipina menyimpulkan bahwa gaya hidup (lifestyle) dan manajemen stres sangat mempengaruhi terjadinya kenaikan kadar gula darah dan komplikasi pada penderita diabetes mellitus tipe 2 .

Perubahan gaya hidup dan peningkatan status ekonomi dapat meningkatkan risiko diabetes mellitus tipe 2, seperti diet tidak sehat, konsumsi gula yang berlebihan, konsumsi lemak dan garam yang tinggi, serta aktivitas fisik yang kurang, semuanya dapat menyebabkan risiko kegemukan yang menjadi pintu masuk diabetes mellitus. Gaya hidup sehat sangat efektif dan murah untuk mengendalikan risiko diabetes mellitus serta mengurangi risiko komplikasi yang ditimbulkan (Anggina, 2010).

Diabetes mellitus merupakan penyakit tidak menular yang harusnya dapat dikendalikan. Diabetes mellitus tipe 2 juga merupakan penyakit kronis yang membutuhkan penatalaksanaan yang berkesinambungan bahkan seumur hidup untuk menjaga kestabilan kadar gula darah dan mencegah komplikasi lebih lanjut. Perkeni (2015) menyatakan bahwa ada lima pilar penatalaksanaan diabetes mellitus tipe 2, yaitu edukasi, terapi nutrisi (diet), latihan jasmani, terapi farmakologi dan monitor kadar gula darah.

Kementerian Kesehatan RI telah meluncurkan program untuk mengendalikan diabetes mellitus melalui Posbindu (Pos Pembinaan Terpadu) untuk memudahkan akses warga melakukan deteksi dini penyakit tidak menular yang salah satunya adalah diabetes mellitus.
Menteri Kesehatan juga menghimbau masyarakat untuk menerapkan aksi CERDIK dalam kehidupan seharihari (Infodatin Kemenkes RI, 2018). Perilaku CERDIK merupakan kepanjangan dari cek kesehatan berkala, enyahkan asap rokok, rajin aktivitas fisik, diet sehat dan seimbang, istirahat cukup, dan kelola stres.

Berdasarkan wawancara dengan petugas kesehatan di PKM Kebonsari Surabaya mengatakan bahwa penderita diabetes mellitus di wilayahnya rutin melakukan kunjungan ke puskesmas dan posbindu, namun angka penderita masih bertambah. Kader kesehatan Kebonsari juga mengatakan bahwa banyak penderita diabetes mellitus yang belum mematuhi pola hidup sehat dan tidak melaukan katifitas jasmani rutin, meraka hanya rutin mengkonsumsi obat antidiabetes saja.

Berdasarkan hal tersebut di atas, peneliti tertarik untuk menggali dan mengeksplorasi pengalaman penderita diabetes mellitus tipe 2 dalam pengendalian kadar gula darah. Metode riset kualitatif dengan desain fenomenologi dipilih dengan alasan merupakan metode yang paling sesuai untuk menggambarkan dan memahami secara mendalam pengalaman individu (Streubert \& Carpenter, 2003). Riset kualitatif ini akan menggambarkan pemahaman yang mendalam penderita diabetes mellitus tipe 2 dalam mengendalikan kadar gula darahnya serta arti dan makna dari pengalaman tersebut.

\section{METODE PENELITIAN}

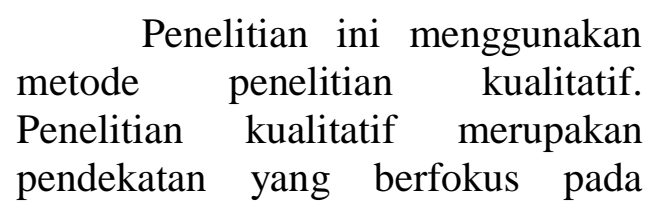


pemahaman tentang fenomena dan seting sosial. Penelitian ini difokuskan melaui proses eksplorasi dan interaksi komunikatif dengan pengakjian yang sistematik, lebih mendalam dan bermakna kepada partisipan mengenai pengalamannya dalam mengendalikan gula darah di rumah.

Pendekatan kualitatif yang digunakan adalah fenomenologi deskriptif. Fenomenologi deskriptif bertujuan untuk menyajikan gambaran yang lengkap mengenai setting sosial dan hubunganhubungan yang terdapat dalam penelitian (Nursalam, 2020). Teknik pengambilan partisipan yang digunakan adalah purposive sampling. partisipan penelitian ini sebanyak 15 penderita diabetes mellitus tipe 2 yang sesuai dengan kriteria inklusi, yaitu penderita diabetes mellitus tipe 2 tanpa komplikasi yang tinggal dengan keluarganya di wilayah Kebonsari Surabaya, berusia di atas 21 tahun, dapat berkomunikasi dengan baik dengan bahasa Indonesia dan mampu menceritakan pengalamannya terkait pengendalian diabetes mellitus serta bersedia menjadi partisipan.

Proses pengambilan data melalui wawancara mendalam (indept interview) yang bertujuan untuk mendapatkan data pengalaman penderita diabetes mellitus tipe2 dalam pengendalian kadar gula darah. Wawancara mendalam berlangsung selama 30-60 menit. Tempat dan waktu wawancara dilakukan sesuai permintaan partisipan, yaitu di rumah masingmasing partisipan pada waktu pagi dan siang hari. Penelitian ini telah mendapatkan persetujuan etik dari Komite Etik Penelitian Kesehatan Universitas Nahdlatul Ulalam
Surabaya dengan No. 089/EC/KEPK/UNUSA/2020.

\section{HASIL PENELITIAN}

\section{Karakteristik Partisipan}

Penelitian ini melibatkan 15 partisipan penderita diabetes mellitus tipe 2. Usia partisipan bervariasi antara 47 tahun sampai 65 tahun. Jenis kelamin partisipan tersebut terdiri dari empat orang laki-laki dan sebelas orang perempuan, dengan lima orang berstatus janda dan sepuluh orang berstatus menikah. Pendidikan partisipan terdiri dari enam orang tamat SMA dan tiga orang tamat SMP, serta enam orang sarjana. Pekerjaan partisipan terbagi menjadi lima orang sebagai ibu rumah tangga dan sepuluh orang masih bekerja. Lama penderita DM tipe 2 bervariasi, minimal 3 tahun sampai 12 tahun. Dari keseluruhan partisipan, sebanyak tujuh orang menyatakan pernah di rawat rumah sakit akibat kadar gula darah yang terlalu tinggi.

\section{Hasil Analisis Penelitian}

Analisis penelitian dengan menggunakan Open Code 4.02 menghasilkan tema:

\section{Pemahaman tentang DM}

Pemahaman partisipan tentang pengertian, penyebab, tanda dan gejala, serta dampak DM masih belum tepat. Pemahaman partisipan tersebut tergambar dari pernyataan sebagai berikut:

"penyakit gula itu penyakit keturunan bu...bapak saya juga punya penyakit gula, makanya saya juga kena gula" (P7)

"Sakit gula ini dibawa sampai mati bu, gak akan bisa sembuh katanya, 
meskipun sudah berobat ya tetap sakit gula" (P2)

"setau saya tanda sakit kencing manis itu orangnya gemuk_seperti saya...." (P9)

"saya perna dengar dari tetangga, penyakit kencing manis itu tidak ada gejalanya, kita tiba-tiba sakit saja, pas diperiksa, gulanya tinggi, gitu bu..." (P11)

“.... Lama-lama lemes saja sampai gak bisa bangun, itu saja sih dampaknya orang puya sakit gula" (P15)

\section{Penyesuaian pola hidup}

Berdasar hasil analisis, partisipan penelitian menunjukkan kemauannya dalam penyesuaian pola hidup penderita diabetes mellitus tipe 2, meliputi pengaturan makan dan minum, olahraga dan mengatasi stres. Penyesuaian pola hidup tersebut tergambar dari pernyataan partisipan sebagai berikut::

"Saya rutin makan tiga kali sehari sekarang dengan tetap mematuhi diet gula darah" (P4)

"Tiap makan nasinya 5-7 sendok makan dan sayurnya saya tambain agak banyak"(P6)

“....kadang saya ganti kentang atau roti, tapi ya tetep mbak, ada sayurnya, ada lauknya, pokonya harus sesuai diet gula mbak" (P4)

"Sekarang tiap pagi jam 5 an gitu sering jalan-jalan pagi muterin rumah ini, dulukan gak perna gini" (P6) “...kita serahkan saja kepada Allah, pasrah dan berdoa gak usa terlalu dipikir, kalo stres gula malah naik, betulkan mbak" (P12)

"sekarang saya bener-bener menjaga makanan saya bu, saya takut gula semakin tinggi, istri saya yang slalu mengatur diet makanan saya" (P8).

\section{Terapi DM}

Berdasar hasil analisi, partisipan penelitian menggunakan pengobatan farmakologi dan nonfarmakologi. Hal tersebut tergambar dari pernyataan partisipan sebagai berikut:

"Saya sekarang minum obat glucodin sama metformin, glucodin tu sebelum makan pagi aja, kalo metformin setelah makan mbak, tiga kali sehari itu" (P5)

“...saya sampai ke alternatif juga, dipijit-pijit dikit gitu kaki saya biar badan gak lemes terus, kesana kalo pas gula lagi tinggi aja, tapi ya insulin tetap mbak" (P3)

"istri saya selalu mengingatkan saya minum obat gula dari dokter, jadi saya gak perna telat, itu saja sih obat yang saya minum bu..." (P13)

\section{Kesulitan dalam pengendalian kadar gula darah}

Berdasarkan hasil analisis, partisipan mengalami kesulitan internal dan eksternal. Hal tersebut tergambar dari pernyataan partisipan sebagai berikut:

"pikiran ini yang sering ganggu, masih ngerasa lapar aja meski sudah makan, ya makan terus lagi hehehe, kadang-kadang gak sadar, ya hayo dimakan..." (P7) 
“...kadang saya lupa gak minum obat, males juga apalagi saat badan rasa enak, ya saya rasa gak perlu minum obat" (P5)

"ya Allah bu, bosan banget saya, pokoknya bosan gitu, bosan dengan obat, dengan diet yang serba diatur, dari dulu ikut aturan terus" (P3)

"...maunya minum obat teratur, tapi kalo gak ada yang ingetin, ya saya jadi lupa juga, suami dan anak sayakan kerja sampe sore" (P5)

\section{PEMBAHASAN}

Hasil penelitian ini mengidentifikasi bahwa pemahaman gejala awal yang dirasakan partisipan terdiri dari gejala utama dan gejala lain. Gejala utama yang dirasakan adalah mudah lapar, mudah haus, sering kencing (Bistara, D. N.,\& Ainiyah, N. 2017). Gejala lain yang dirasakan adalah penurunan berat badan, mudah mengantuk, badan lemas, dan luka kaki lama sembuh sembuh. Partisipan lebih mengenali gejala lain dibandingkan gejala klasik berupa cepat lapar, cepat haus, dan sering kencing sebagai tanda awal penyakit diabetes. Penelitian Black dan Hawks (2014) menjelaskan bahwa manifestasi diabetes melitus saat didiagnosis yaitu peningkatan frekuensi buang air kecil (poliuri), peningkatan rasa haus dan minum (polidipsi), dan peningkatan makan (polifagi). Poliuri, polidipsi, dan polifagi sering dirujuk sebagai gejala klasik diabetes melitus. Gejala lain yaitu penurunan berat badan, pandangan kabur berulang, pruritus, infeksi kulit, vaginitis, ketonuria, lemah, letih, pusing, dan bahkan sering asimtomatik. Pengertian diabetes sebagai penyakit keturunan sebagaimana pernyataan partisipan dalam penelitian ini belum sepenuhnya tepat. Keturunan merupakan salah faktor risiko terjadinya diabetes mellitus. Faktor keturunan/genetik ini berkaitan dengan riwayat keluarga dengan diabetes mellitus tipe 2. Anggota keluarga yang lain kemungkinan lebih besar terserang diabetes mellitus dibanding keluarga yang tidak memiliki riwayat diabetes mellitus. Penelitian yang dilakukan oleh Bianco, Pomara, Raccuglia, Bellafiore, dan Battaglia (2013) menunjukkan adanya hubungan signifikan positif $(\mathrm{p}<0.05)$ pada klien diabetes mellitus tipe 2 dengan riwayat keluarga diabetes mellitus, dibandingkan keluarga tanpa riwayat diabetes mellitus. Perbandingan keluarga yang mempunyai riwayat diabetes mellitus dengan keluarga sehat yang tidak memiliki diabetes mellitus mencapai $5,33 \%$ dan $8,33 \%$ bila dibandingkan dengan keluarga sehat yang memperlihatkan angka hanya $1,96 \%$.

Penelitian ini mengidentifikasi upaya yang dilakukan partisipan terhadap diabetes mellitus yang diderita, salah satunya dengan penyesuaian pola hidup, meliputi pengaturan makan minum, olahraga dan pengaturan stress (Hatmanti, N. M, 2017). Upaya yang telah dilakukan partisipan tersebut telah sesuai dengan penatalaksanaan diabetes mellitus tipe 2 yang dicetuskan Perkeni (2015), meskipun belum maksimal. Penatalaksanaan tersebut meliputi empat pilar yaitu pengaturan pola makan dan monitoring kadar gula darah, latihan jasmani, intervensi farmakologi dan promosi kesehatan. Pengaturan pola makan (diet) bertujuan adalah untuk 
memperbaiki kebiasaan makan klien supaya kontrol metabolik tetap baik dalam mempertahankan kadar gula darah normal, memberi cukup energi, mempertahankan berat badan normal, meningkatkan sensitivitas reseptor insulin dan mencegah komplikasi akut maupun kronik (Kumala, 2014). Pengaturan makan yang dianjurkan bagi klien diabetes mellitus tipe 2 adalah makanan dengan komposisi seimbang dalam karbohidrat, protein dan lemak sesuai standar yang dianjurkan yaitu karbohidrat $50 \%$, protein $20 \%$ dan lemak $30 \%$ (Tandra, 2013). Olahraga yang telah dilakukan partisipan penelitian merupakan upaya menuju hidup sehat, namun berdasarkan pernyataan partisipan bahwa aktifitas olahraga mereka belum optimal. Partisipan hanya berfokus pada olahraga ringan saja yaitu jalan kaki biasa. Hal tersebut tidak sesuai dengan anjuran ADA (American Diabetic Association) bahwa jenis latihan fisik yang dapat dilakukan oleh klien diabetes mellitus tipe 2 adalah olahraga ringan (jalan kaki biasa) selama 30 menit, olahraga sedang (jalan kaki cepat/jogging) selama 20 menit dan olahraga berat (aerobic) selama 10 menit. Latihan fisik harus dilakukan secara rutin minimal tiga sampai lima kali dalam semingu dengan interval kurang lebih 30 menit (ADA, 2011).

Hasil penelitian ini menjelaskan bahwa partisipan diabetes mellitus tipe 2 mempunyai upaya yang berbeda dalam hal pengobatan, yaitu melalui obat antidiabetes (farmakologi) dan herbal serta alternative (nonfarmakologi). Partisipan melakukan upaya pengendalian dengan pengobatan sesuai dengan kemampuan dan pengetahuan mereka. Partisipan mengkonsumsi obat medis secara beragam. Obat antidiabetes tersebut ada yang didapatkan dari dokter, ada juga yang langsung beli di apotek tanpa resep dokter. Partisipan ada yang mengkonsumsi secara rutin dan ada juga yang sebaliknya. Kegagalan pengendalian kadar gula darah pada penderita diabetes mellitus tipe 2 setelah pengaturan diet dan latihan fisik, maka penderita memerlukan pemberian obat-obatan antidiabetes untuk mencegah komplikasi. Permulaan pengobatan biasanya dengan pemberian satu jenis OAD (obat anti diabetes), kemudian bisa diberikan lebih dari satu jenis OAD untuk lebih efektif menurunkan kadar gula darah (Tandra, 2013). Black dan Hawks (2014) menjelaskan bahwa penggunaan terapi farmakologi dilakukan jika klien tidak dapat mencapai kadar glukosa darah normal atau mendekati normal melalui pengaturan diet dan olahraga. Penderita diabetes melitus tipe 2 secara prinsip mengalami kerusakan metabolisme karena gangguan sekresi insulin dan resistensi insulin, oleh karena itu diperlukan terapi yang merangsang sekresi insulin, termasuk obat oral antihiperglikemik maupun insulin (Meneilly, Knip, \& Tessier, 2013).

Hasil penelitian ini telah mengidentifikasi partisipan yang mengalami kesulitan dalam pengendalian DM. Berdasarkan pernyataan partisipan bahwa faktor penyebabnya berasal dari faktor internal dan eksternal. Faktor internal meliputi kesulitan menahan rasa lapar, ketidakteraturan minum obat, keterbatasan fisik dan perasaan bosan terkait diet dan terapi DM. 
Bhattacharya dan Gauri (2012) dalam penelitian kualitatifnya menyatakan bahwa ketidakpatuhan klien diabetes mellitus tipe 2 dalam perawatan dan pengobatan dikarenakan penyakit diabetes mellitus tipe 2 tanpa gejala pasti, pengetahuan yang tidak adekuat dan kurang percaya kepada pengobatan medis, serta program diet dan latihan fisik sering tidak sesuai dengan sosial budaya partisipan. Bhattacharya dan Gauri (2012) dalam penelitian kualitatifnya menyatakan bahwa ketidakpatuhan klien diabetes mellitus tipe 2 dalam perawatan dan pengobatan dikarenakan penyakit diabetes mellitus tipe 2 tanpa gejala pasti, pengetahuan yang tidak adekuat dan kurang percaya kepada pengobatan medis, serta program diet dan latihan fisik sering tidak sesuai dengan sosial budaya partisipan.

\section{SIMPULAN}

Simpulan dari penelitian ini adalah adanya makna dan arti ketidakoptimalan pengendalian kadar gula darah pada penderita diabetes mellitus tipe 2 di wilayah Kebonsari Surabaya. Kurangnya pemahaman partisipan tentang diabetes melitus sehingga mempengaruhi pengendalian kadar gula darah. Pengaturan pola hidup yang sehat sudah cukup baik dilakukan oleh partisipan. Tidak semua partisipan mengkonsumsi obat farmakologi, namun ada juga nonfarmakologi.. Beberapa partissipan juga mengalami kesulitan internal dan eksternal seperti adanya rasa bosan dengan penatalaksanaan diabetes mellitus. Berdasarkan tema-tema yang didapatkan dalam penelitian ini, dapat dijadikan dasar membuat pedoman pengendalian diabetes mellitus dalam keluarga.

\section{DAFTAR PUSTAKA}

Allender, J.A., Rector, C. \& Warner, K.D. (2014). Community health nursing: promoting and protecting the public's health. Seventh edition. Philadelphia: Lippincott Williams \& Wilkins.

Anggina L.L., Hamzah Ali, Pandhit. (2010). Hubungan antara dukungan sosial keluarga dengan kepatuhan pasien diabetes mellitus dalam melaksanakan program diet di poli penyakit dalam RSUD Cibabat Cimahi. Jurnal Penelitian Kesehatan Suara Forikes

Badriah, S., Wiarsih, W., \& Permatasari, H. (2014). Pengalaman keluarga dalam merawat lanjut usia dengan diabetes mellitus. Jurnal Keperawatan Indonesia, 17(2), 57-64.

Bhattacharya, G. (2012). Selfmanagement of type 2 diabetes among African Americans in the Arkansas Delta: a strengths perspective in social-cultural context. Journal of Health Care for the Poor and Underserved, 23(1), 161-178. Context. Journal of Health Care, 23(2012):161-178.

Bianco, A., Pomara, F., Raccuglia, M., Bellafiore, M., Battaglia, G., Filingeri, D., ... \& Palma, A. (2014). The relationship between type 2 diabetes family history, body composition and blood basal glycemia in sedentary people. Acta diabetologica, 51(1), 79-84.. 
Journal of Acta Diabetologica Italia. DOI 10.1007/s00592-013-0562-x.

Bistara, D. N., \& Ainiyah, N. (2017). Hubungan pengetahuan dengan kepatuhan diet pada penderita diabetes mellitus di posyandu lansia cempaka kelurahan tembok dukuh Kecamatan Bubutan Surabaya. Journal of Health Sciences, 11(1), 51-57.

Black, J.M. \& Hawks, J.H. (2014). Keperawatan Medikal bedah: manajemen klinis untuk hasil yang diharapkan. Edisi 8. Singapore: Elselvier.

Cresswell, J.W. (2010). Research design: Qualitative, quantitative, and mixed methode approach. Thirth Edition. California: SAGE Publication.

Infodatin Kemenkes RI (2018). Hari diabetes sedunia tahun 2018. www.kemkes.go.id

International of diabetic Federation (IDF) Diabetes Atlas. (2017). Diabetes prevalence, mortality, and healthcare expenditures.

http://www.idf.org/diabetesat la.

Hatmanti, N. M. (2017). Hubungan antara self efficacy dengan quality of life pada pasien diabetes mellitus tipe 2 di wilayah kerja Puskesmas Kebonsari Surabaya. Journal of Health Sciences, 10(2).

Herlina, S., \& Sitorus, S. (2018). Determinan efikasi diri pada pasien diabetes mellitus. Jurnal Ilmiah Ilmu Keperawatan Indonesia, 8(04), 522-527.

Kemenkes RI. (2018). Riset kesehatan dasar 2018.
Kementerian Kesehatan

Badan Penelitian dan Pengembangan Kesehatan.

Kumala, D.R. (2014). Diabetes bukan untuk ditakuti. Jakarta: FMedia.

Leake, A. R. (2003). Selfmanagement by uninsured Filipino immigrants with type 2 diabetes (Doctoral dissertation, University of Hawaii at Manoa)

Nursalam. (2020). Metodologi penelitian ilmu keperawatan. Jakarta: Salemba Medika

Perkumpulan Endokrinologi Indonesia (Perkeni). (2015). Konsensus pengelolaan dan pencegahan diabetes mellitus tipe 2 di Indonesia. Jakarta: Perkumpulan Endokrinologi Indonesia. http://www.perkeni.org

Ridwan, A., Barri, P., \& Nizami, N. H. (2018). Efektivitas diabetes self management education melalui sms terhadap pengetahuan penderita diabetes mellitus: a pilot study. Idea Nursing Journal, 9(1).

Soegondo, S., Soewondo, P. \& Subekti, I. (2009). Penatalaksanaan diabetes mellitus terpadu. Jakarta: Balai Penerbit FKUI.

Suyono, S. (2011). Penatalaksanaan diabetes mellitus terpadu, patofisiologi diabetes mellitus. Edisi ke-2. Jakarta : Balai Penerbit FKUI.

Tandra, H. (2013). Life healthy with diabetes. Yogyakarta: Rapha Publishing.

World Health Organization (WHO). (2016). Country and regional data on diabetes. World Health Organization. 